\title{
MARKET EXPLORATION OF BAKSO CULINARY TOURISTS IN MALANG CITY, INDONESIA
}

\author{
Ahmadintya Anggit Hanggraito* \\ State Polytechnic of Banyuwangi \\ *Corresponding author's e-mail: ahmadintya.anggithanggraito@poliwangi.ac.id
}

\begin{abstract}
Bakso is one of the top Indonesian local culinary from Malang City. This study tries to reveals types of food-related behaviour and culinary experiences in psychographic segmentation for bakso culinary tourism in Malang City. In addition, identifying the motivational factors of Bakso Malang tourists is useful for the development of culinary tourism. The study employed qualitative descriptive method a method. This study using 210 samples for explaining a statistic of bakso culinary tourists in Malang city. The result of study reveals the main type food-related behaviour in bakso market segmentation in Malang city namely, Experiencers. Then, the main motivational factor of bakso culinary tourists in is related to hedonism and leisure. this result represented an exploration of market segmentation and motivation factors of bakso culinary tourists. That could be an in-depth consideration of the bakso restaurant even for culinary development strategies in Malang City. Bakso Malang's consistent understanding of market management will provide important intangible capital for the development of culinary products in Malang City.
\end{abstract}

Keywords: Bakso; Culinary Tourism; Market Segmentation; Motivational Factors; Local Culinary

\section{INTRODUCTION}

At this time, local food products have contributed to the development of culinary tourism from a tourism destination. UNWTO (2017), explained that there are many things that attract tourists to visit a culinary-based cultural tourism destination. Furthermore, tourist motivation when visiting culinary tourism destinations is as much as $63 \%$ to travel to culinary places or food tours, and as many as $62 \%$ learn local food through direct practice (cookery workshops) (UNWTO, 2017). In addition, UNWTO (2017) states that an estimated $30 \%$ of tourism revenue 
comes from culinary or gastronomic tourism (Leewellyn \& Abdillah, 2020). Therefore, proper management of food products will help to increase the development of culinary tourism.

Culinary tourism is all about seeking experience and food participation from other people, which is not limited to consuming, processing, and presenting food (Long, 2004). The link with sustainable tourism, culinary is a strong attraction and able to improve the welfare of the local population (Wijayanti, 2020). Culinary tourism is a growing niche in the industry, so it is expected to get stronger as more providers and tourists realize it (Long, 2013). In this case, Malang City has big capital in development strategic for culinary system.

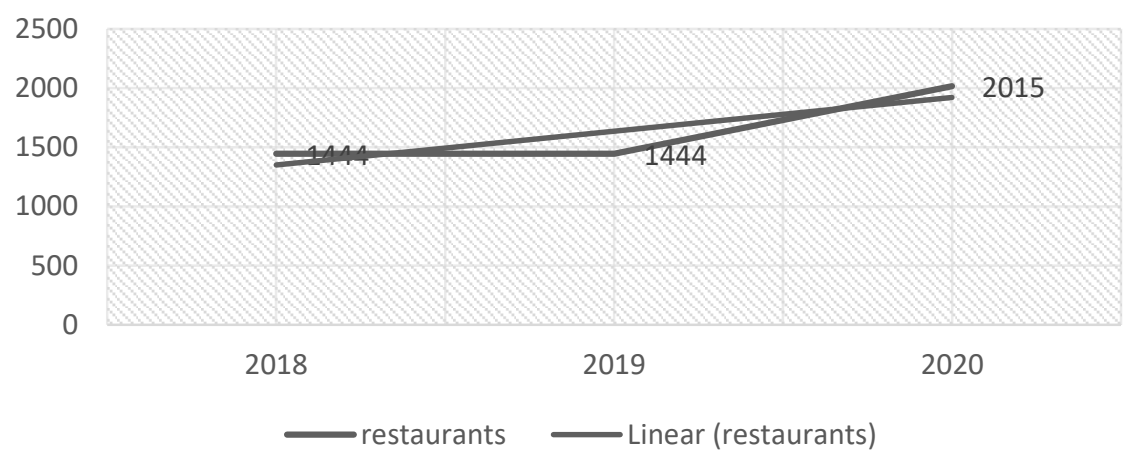

Figure 1. Growth Chart for Restaurants in Malang City Source: Statistics Malang Municipality (2021)

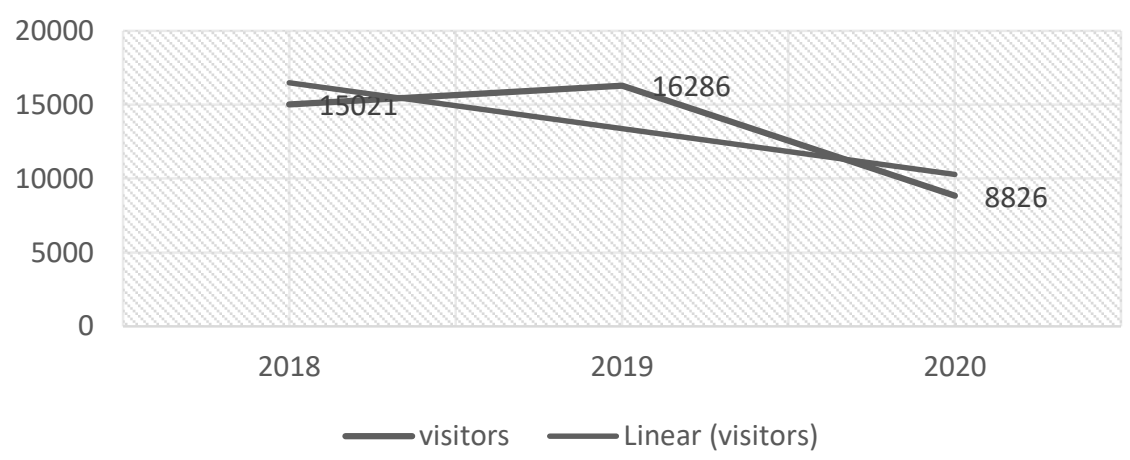

Figure 2. Number of Visitors in Malang City, 2018-2020 Source: Statistics Malang Municipality (2021)

Figure 1 shows that Restaurants in Malang City got significant growth during the Covid19 pandemic in 2020 . This is inversely proportional to the fluctuating number of tourist arrivals from 2018 until to 2020. Figure 2 explains in 2019 tourists coming to Malang City increased by $8.42 \%$ from 2018 . However, in 2020 tourists coming to Malang city actually decreased by 
$52.45 \%$. In addition, there is an increase in the average food expenditure per capita of the population by $4.82 \%$ in 2020 (Statistics Malang Municipality, 2021). This shows that food will remain an important product. Thus, foods will be able to provide many choices of culinary tourism for tourists who visited to Malang City.

One of the famous culinary tourism products in Indonesia is Bakso Malang. Bakso or known as Indonesian traditional meatballs is one of the comminute meat products and its popularity in all classes of Indonesian society especially the youngsters has attracted interest of the meat processors as a business opportunity (Purnomo \& Rahardiyan, 2008). Bakso popularity in Indonesia has attracted interest in the traditional food as a business opportunity by the Indonesian food industry (Rahardiyan, 2004). In general, a Bakso Malang contains beef meatballs as the main menu. Beef meatballs are a source of animal protein because beef contains protein that is needed by the human body (Tarwotjo et al., 1971; Hartono, et.al., 2011). Bakso Malang can be combined with various additional menu variations such as stuffed fried dumplings, yellow noodles, stuffed white tofu, stuffed fried tofu, vermicelli, dumplings and various other fillings according to taste. However, every Bakso restaurant in Malang City has represent different quality and quantity.

The diversity of Bakso Restaurants in Malang City shows that the good meatball is defined by authentic local food, structured time, and specific location. understanding of Bakso Malang as a local culture will help to define market segmentation for culinary tourists who visited Malang indirectly. According to Assauri (2015), market segmentation is the activity for dividing the market into different groups. Socio-demographic segmentation related to culinary tourism is described in variables such as age, gender, education, income, marital status, religion, and generation (Cho et al., 2017). People in the same demographic group may exhibit various psychographic features (Kotler, 2007). In this case, a person's choice can be related to the presentation of food, the way it is served, a person's position in the group. So, these things can be a profile predictor of tourists who visit a culinary tourism destination.

In addition to Socio-demographic Segmentation, it is necessary to identify the psychographic segment of tourists from a culinary tour of Bakso Malang. Psychographics is 
often interpreted as a measurement of AIO (Activity, Interest, Opinion), namely the measurement of activities, interests and consumer opinions (Kotler, 2007). Tourist attitudes related to food can be a classification model for the culinary tourist segment from Bakso Malang. Björk \& Kauppinen-Räisänen (2016) explain that, culinary tourists can be distinguished by their attitudes towards local food and local food markets where this has an impact on food-related behaviour, such as food-related experiences. Food-related experiences according to Björk \& Kauppinen-Räisänen (2016) can be seen from; local food culture, homemade food, the newest of food, food authenticity, locality of food, original of food, healthy food, uniqueness of food, participation in food preparation, well-known food, different styles of eating, dining companionship, food aesthetics, dining in the restaurant, the restaurant environment, the restaurant atmosphere, and the absence of stress.

Socio-Demographic and Psychographic segmentation of Bakso in Malang City shows the detail of classification from culinary tourist groups. To find out more about each other's feelings, identify motivation from culinary tourists is needed. Thus, the right strategy pattern for the convenience of tourists from various bakso restaurants in the future will be mapped easily. The motivation to visit a destination that makes food to main goal, is explained by Castillo-Canalejo, et al. (2020) in three factors, namely: (1) Food experience and novelty: New eating or drinking experiences; Eat/drink my favourite food/drink; The desire to try something new; Relaxation, disconnection from daily life; and Good reputation of the place to eat; (2) hedonism and leisure: Spend time with relatives, friends, and colleagues; Being a leisure; and Good quality or price relationship; (3) Experience on the work: work meetings; and develop networking opportunities. Determining the motivational factors of culinary tourists is expected to provide materials for the development of sustainable culinary tourism in Malang City.

Sustainable culinary tourism needs to identify market segments and the motivations of culinary tourists. In-depth market exploration is either of the key factors for the success in culinary tourism development, that synergy of various components of the development system within the tourism ecosystem framework (Kemenparekraf, 2019). Referring to this statement, Author aims to describe the market segmentation and motivational factors of Bakso Malang 
culinary tourists who visiting Malang City through a quantitative approach. Referring to this statement, the author aims to quantitatively describe the market segmentation and motivational factors of Bakso Malang culinary tourists visiting Malang City. This result of the study tries to provide contributions material for a strategic plan to local culinary management development in Malang City. Especially, culinary market segmentation exploration and motivational factor identification.

\section{METHODS}

\section{Research Type, Sampling and Data Collection}

This study employed qualitative descriptive method as the research methodology. This study analyse the data descriptively and the presentation of the result was in a form of explanation of value which would be supported by data presented in the form of tables. Suryana (2010) affirms that descriptive research is focused to make a description systematically and accurately based on facts about a certain object. Then, for qualitative approach, this study concerns about the quality of work are evident in discussions about formulating both research design and questions within explicit theoretical and philosophical traditions; accessing and entering settings; selecting, collecting, and analysing data; and building a case for conclusions (Freeman et al., 2007). So in this case, Quantitative data will be explained through the meaning of the exploration of various theories related to this study. It is designed to produce effective and targeted conclusions and recommendations.

Purposive sampling technique is used in this research. The sample selection is based on the researcher's personal research which states that the selected sample is truly representative (Sudaryono, 2019). The sample were respondents who had ever enjoyed bakso Malang in Malang City. According to Statistics Malang Municipality (2020), in 2020 the population of tourists is 698,396 people and the population of Malang City is 843,810 people, so in other words the culinary tourism population in 2020 is 1,542,206 people. In this study, the number of samples used Slovin proposed by Umar (2013): 


$$
s=\frac{N}{1+N e^{2}}
$$

\section{Figure 3. Slovin's Formula}

Source: Umar (2013)

The following is the calculation for sample in this study:

$$
s=\frac{1.542 .206}{1+1.542 .206(0.1)^{2}}=99.99
$$

Note:

$\mathrm{S}=$ Sample

$\mathrm{N}=$ Population

$\mathrm{e}=$ degree of accuracy

Based on Slovin's formula, the sample required is 100 respondents. To enrich the results, through accidental sampling, this study involved 210 respondents who had enjoyed Bakso Malang in Bakso Restaurant in Malang City. The distribution of questionnaires using the google form is carried out online via WhatsApp, and Instagram. From the results of the distribution of the questionnaires, Respondents who participated consisted of 98 males (46.67\%), and 112 females (53.34\%).

\section{Measurement}

The First section of measurement is to collect respondent's Socio-demographic information (gender and age), bakso restaurant's information, and travel behavior (travel experience and frequency). Then, In Section 2, three items measured respondent's attitudes to food and travelling and the impact of food on destination choice. Respondents indicated on a four-point scale (1) very unimportant", until (4) "very important". This section asks about three aspects: food and eating as a motive for travelling; food and eating experiences when choosing a destination; and food and eating for travel satisfaction. This survey shows types of psychographics on their Attitude towards food. The psychographic segment of culinary tourists can be classified into three types: Experiencer, who considers food important for destination selection; Enjoyers, who have a positive attitude towards food; and Survivors, who consider that their local food destination covers physiological needs (Björk \& Kauppinen-Räisänen, 
2016). The higher the level of relevance of the experience item to food, the more it can be included in the Experiencer category.

Section 3 consisted of two parts measuring respondents' interest in food-related information and information sources used to determine travel destinations. This section asks about two aspects: information about local bakso Malang and local bakso Malang restaurants before travelling. This section included 13 items to cover main information sources from consumers when check for travel information. Last section of market segmentation, Items in Section 4 explored dimensions that contribute to travellers' food experiences to shows psychographic segmentation on the bakso culinary tourism. Respondents indicated on a fourpoint scale (1) very disagree", until (4) "very agree". this section generates 17 items using research on food consumption in tourism (Kim et al., 2009; Mak et al., 2012; Björk, \& Kauppinen-Räisänen, 2016). Last section of measurement is collected main motivation from culinary tourist when they come to bakso restaurant in Malang city. Respondents indicated on a four-point scale (1) very disagree", until (4) "very agree". this section generates three motivation factors: food experience and novelty; hedonism and leisure; and relationship of the experience with work.

\section{Data Analyst}

Questionnaire data was processed through descriptive statistical analysis. Statistics describe a summary of research data such as intent, standard deviation, variance, mode (Soecahyadi, 2012). The Mean Value becomes a statistical description of respondents related to market segmentation and motivational factors for culinary tourists. This study uses qualitative data from social media to increase the understanding of meaning. This qualitative data consists of all a comment from the various social media or travel websites that has explained about culinary experiences of bakso Malang in Malang city. All of comments representing various opinion about bakso malang that enjoyed in Malang City. Then, for data conclusions, the following stages of data related to market segmentation and culinary tourism 
motivation of Bakso Malang in Malang City. This stage follows the model of Milles \& Huberman (2003) in Ayustina (2019):

a. Data reduction. First, editing, segmenting, and summarizing the data that has been collected. Then, coding and interpreting, and associating activities with certain patterns. Finally, the process of conceptualization and presentation, where abstract concepts development is part of data reduction.

b. Data Presentation. This stage provides a descriptive and systematic summary in order to find out the main ideas easily. Then, interpret them critically.

c. Conclusions or Verification. Drawing conclusions logically by following previous step. Then, conclusions can be noted and verified.

\section{RESULT AND DISCUSSION}

\section{Bakso Malang in Malang City}

In general, Bakso Malang has spread to various restaurants in Malang City. Based on survey, there are various alternative choices of Bakso restaurants in Malang City that have been visited by the respondents.

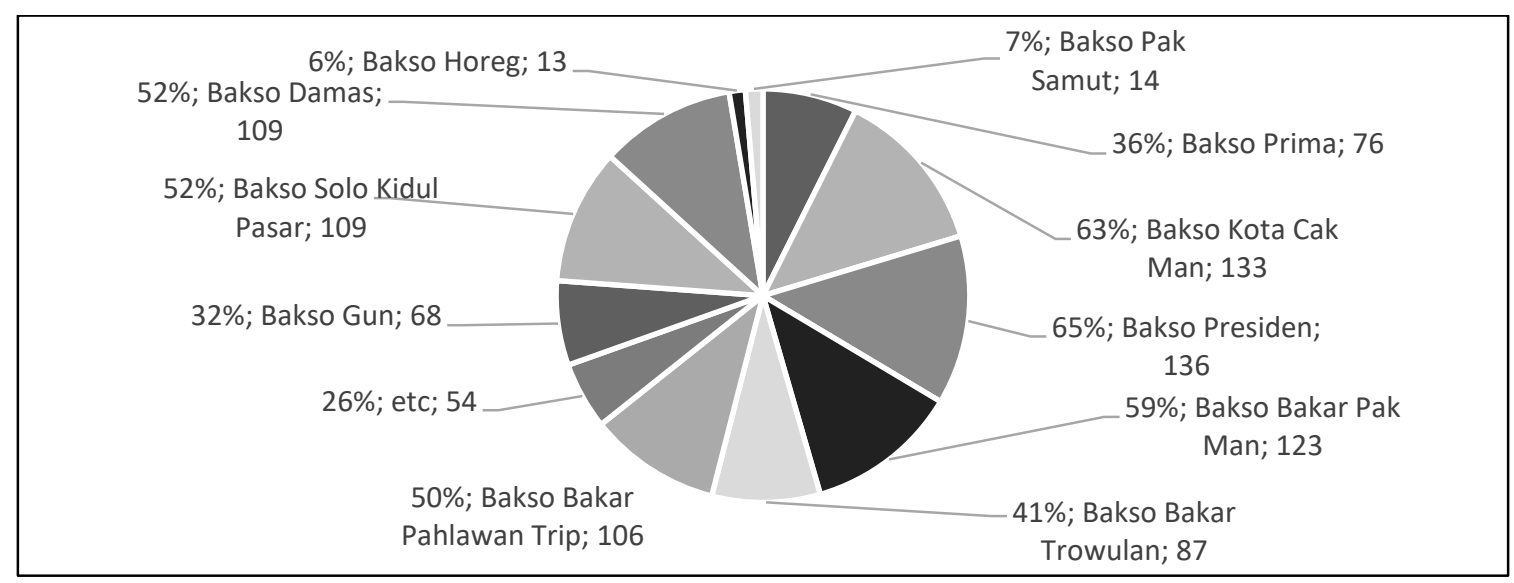

Figure 4. Choice of Bakso restaurant in Malang Source: Survey Results (2021)

Figure 4 shows most visited bakso restaurants by respondents. The top five include: Bakso President (65\%), Bakso Cak Man (63\%), Bakso bakar Pak Man (59\%), Bakso Damas 
(52\%), Bakso Solo Kidul Pasar (52\%). Respondents not only enjoyed bakso at one restaurant, but also at various other bakso restaurants in Malang City. In addition, there're about $26 \%$ of respondents who have choice of other bakso restaurants for visited. The selected restaurants include Bakso Cak Toha, Bakso Arief, Bakso Kirun, Bakso Surya, to Bakso Cart Mobile.

\section{Socio-Demographic Segmentation of Bakso Culinary Tourists in Malang City}

Table 1. Statistic Socio-Demographic Segmentation of Bakso Culinary Tourists in Malang City

\begin{tabular}{|c|c|c|c|c|}
\hline \multirow{2}{*}{ Variable } & \multirow{2}{*}{ Category } & \multirow{2}{*}{ Total } & \multicolumn{2}{|c|}{ Gender } \\
\hline & & & Male & Female \\
\hline Sex & & 210 & 98 & 112 \\
\hline & Percentage & $100 \%$ & $46,7 \%$ & $53,3 \%$ \\
\hline \multirow{10}{*}{ Age } & \multirow{2}{*}{$<20$} & 4 & 3 & 1 \\
\hline & & $1,9 \%$ & $1,4 \%$ & $0,5 \%$ \\
\hline & \multirow{2}{*}{$21-30$} & 90 & 36 & 54 \\
\hline & & $42,9 \%$ & $17,1 \%$ & $25,7 \%$ \\
\hline & \multirow{2}{*}{$31-40$} & 103 & 53 & 50 \\
\hline & & $49,0 \%$ & $25,2 \%$ & $23,8 \%$ \\
\hline & \multirow{2}{*}{$41-50$} & 7 & 2 & 5 \\
\hline & & $3,3 \%$ & $1,0 \%$ & $2,4 \%$ \\
\hline & \multirow{2}{*}{$>50$} & 6 & 4 & 2 \\
\hline & & $2,9 \%$ & $1,9 \%$ & $1,0 \%$ \\
\hline \multirow{11}{*}{ Origin } & Percentage & $100 \%$ & $46,7 \%$ & $53,3 \%$ \\
\hline & \multirow{2}{*}{ Malang City } & 113 & 56 & 57 \\
\hline & & $53,8 \%$ & $26,7 \%$ & $27,1 \%$ \\
\hline & \multirow{2}{*}{$\begin{array}{l}\text { Greater Malang area (outside Malang City but } \\
\text { still includes Malang Regency and Batu City) }\end{array}$} & 25 & 11 & 14 \\
\hline & & $11,9 \%$ & $5,2 \%$ & $6,7 \%$ \\
\hline & \multirow{2}{*}{$\begin{array}{l}\text { From outside Greater Malang area (but still in } \\
\text { East Java) }\end{array}$} & 36 & 18 & 18 \\
\hline & & $17,1 \%$ & $8,6 \%$ & $8,6 \%$ \\
\hline & \multirow{2}{*}{$\begin{array}{l}\text { From Outside East Java (but still covers Java } \\
\text { Island) }\end{array}$} & 23 & 10 & 13 \\
\hline & & $11,0 \%$ & $4,8 \%$ & $6,2 \%$ \\
\hline & \multirow{2}{*}{ From Outside Java } & 13 & 3 & 10 \\
\hline & & $6,2 \%$ & $1,4 \%$ & $4,8 \%$ \\
\hline \multirow{9}{*}{ Education } & Percentage & $100 \%$ & $46,7 \%$ & $53,3 \%$ \\
\hline & \multirow{2}{*}{ Elementary/junior high/high school } & 7 & 1 & 6 \\
\hline & & $3,3 \%$ & $0,5 \%$ & $2,9 \%$ \\
\hline & \multirow{2}{*}{ Vocational School } & 6 & 2 & 4 \\
\hline & & $2,9 \%$ & $1,0 \%$ & $1,9 \%$ \\
\hline & \multirow{2}{*}{ Bachelor degree } & 142 & 71 & 71 \\
\hline & & $67,6 \%$ & $33,8 \%$ & $33,8 \%$ \\
\hline & \multirow{2}{*}{ Postgraduate } & 55 & 24 & 31 \\
\hline & & $26,2 \%$ & $11,4 \%$ & $14,8 \%$ \\
\hline \multirow{9}{*}{$\begin{array}{l}\text { Money spent } \\
\text { for one visit } \\
\text { (Average) }\end{array}$} & Percentage & $100 \%$ & $46,7 \%$ & $53,3 \%$ \\
\hline & \multirow{2}{*}{$<\operatorname{Rp} 25.000$} & 54 & 23 & 31 \\
\hline & & $25,7 \%$ & $11,0 \%$ & $14,8 \%$ \\
\hline & \multirow{2}{*}{ Rp 25.000 - Rp 50.000} & 89 & 39 & 50 \\
\hline & & $42,4 \%$ & $18,6 \%$ & $23,8 \%$ \\
\hline & \multirow{2}{*}{ Rp 50.000 - Rp 100.000} & 58 & 31 & 27 \\
\hline & & $27,6 \%$ & $14,8 \%$ & $12,9 \%$ \\
\hline & Bn $100000-R n 250000$ & 9 & 2 & 7 \\
\hline & Кр 100.000 - Кр 250.000 & $4,3 \%$ & $1,0 \%$ & $3,3 \%$ \\
\hline & Percentage & $100 \%$ & $46,7 \%$ & $53,3 \%$ \\
\hline
\end{tabular}




\begin{tabular}{|c|c|c|c|c|}
\hline \multirow{2}{*}{ Variable } & \multirow{2}{*}{ Category } & \multirow{2}{*}{ Total } & \multicolumn{2}{|c|}{ Gender } \\
\hline & & & Male & Female \\
\hline \multirow{20}{*}{ Profession } & \multirow{2}{*}{ Civil servant/Gov. Corp. /Government } & 48 & 21 & 27 \\
\hline & & $22,9 \%$ & $10,0 \%$ & $12,9 \%$ \\
\hline & \multirow{2}{*}{ Entrepreneur } & 48 & 25 & 23 \\
\hline & & $22,9 \%$ & $11,9 \%$ & $11,0 \%$ \\
\hline & \multirow{2}{*}{ Private employees } & 45 & 26 & 22 \\
\hline & & $21,4 \%$ & $12,4 \%$ & $10,5 \%$ \\
\hline & \multirow{2}{*}{ Lecturer } & 23 & 11 & 12 \\
\hline & & $11,0 \%$ & $5,2 \%$ & $5,7 \%$ \\
\hline & \multirow{2}{*}{ Military/Police } & 1 & 1 & - \\
\hline & & $0,5 \%$ & $0,5 \%$ & $0,0 \%$ \\
\hline & \multirow{2}{*}{ Health workers } & 5 & 3 & 2 \\
\hline & & $2,4 \%$ & $1,4 \%$ & $1,0 \%$ \\
\hline & \multirow{2}{*}{ Student } & 9 & 3 & 6 \\
\hline & & $4,3 \%$ & $1,4 \%$ & $2,9 \%$ \\
\hline & \multirow{2}{*}{ Freelancer } & 4 & 4 & - \\
\hline & & $1,9 \%$ & $1,9 \%$ & $0,0 \%$ \\
\hline & \multirow{2}{*}{ Housewife } & 21 & - & 21 \\
\hline & & $10,0 \%$ & $0,0 \%$ & $10,0 \%$ \\
\hline & \multirow{2}{*}{ Etc. } & 6 & 3 & 3 \\
\hline & & $2,9 \%$ & $1,4 \%$ & $1,4 \%$ \\
\hline \multirow{9}{*}{$\begin{array}{l}\text { Visits to } \\
\text { Malang } \\
\text { Meatballs } \\
\text { Malang } \\
\text { (average per } \\
\text { month in a } \\
\text { year) }\end{array}$} & $\begin{array}{l}\text { Percentage } \\
\end{array}$ & $100 \%$ & $46,7 \%$ & $53,3 \%$ \\
\hline & \multirow{2}{*}{$\begin{array}{l}<\text { Once (sometimes never to Malang City in a } \\
\text { month) }\end{array}$} & 52 & 23 & 29 \\
\hline & & $24,8 \%$ & $11,0 \%$ & $13,8 \%$ \\
\hline & \multirow{2}{*}{ Once } & 28 & 15 & 13 \\
\hline & & $13,3 \%$ & $7,1 \%$ & $6,2 \%$ \\
\hline & \multirow{2}{*}{$2-5$ times } & 70 & 38 & 32 \\
\hline & & $33,3 \%$ & $18,1 \%$ & $15,2 \%$ \\
\hline & \multirow{2}{*}{$>5$ times } & 60 & 18 & 42 \\
\hline & & $28,6 \%$ & $8,6 \%$ & $20,0 \%$ \\
\hline \multirow{13}{*}{$\begin{array}{l}\text { Main Source } \\
\text { Information } \\
\text { location of } \\
\text { Bakso } \\
\text { Restaurant }\end{array}$} & Percentage & $100 \%$ & $46,7 \%$ & $53,3 \%$ \\
\hline & \multirow{2}{*}{ Family } & 41 & 20 & 21 \\
\hline & & $19,5 \%$ & $9,5 \%$ & $10,0 \%$ \\
\hline & \multirow{2}{*}{ Friends } & 58 & 24 & 34 \\
\hline & & $27,6 \%$ & $11,4 \%$ & $16,2 \%$ \\
\hline & \multirow{2}{*}{ TV Program } & 2 & 1 & 1 \\
\hline & & $1,0 \%$ & $0,5 \%$ & $0,5 \%$ \\
\hline & Tourism Dectination Wehcite & 2 & 1 & 1 \\
\hline & tounsm Lestination vvensile & $1,0 \%$ & $0,5 \%$ & $0,5 \%$ \\
\hline & Social Media (Example. Youtube, WA, & 106 & 50 & 56 \\
\hline & Instagram, etc) & $50,5 \%$ & $23,8 \%$ & $26,7 \%$ \\
\hline & Blogaer Website (Example Trip Advisor) & 1 & 1 & - \\
\hline & Dlogger vvedosile (Example, Imp Aavison) & $0,5 \%$ & $0,5 \%$ & $0,0 \%$ \\
\hline & Percentage & $100 \%$ & $46,7 \%$ & $53,3 \%$ \\
\hline
\end{tabular}

Source: Survey Results (2021)

Table 1 showed that the age of bakso connoisseurs was dominated by productive and young age. The majority of bakso Malang connoisseurs are dominated by age of 31-40 years (103 respondents, $49.04 \%$ ), and age of $21-30$ years (90 respondents, $42.86 \%$ ). On average, in a year, 70 respondents (33.34\%) admitted that they enjoyed bakso 2 to 5 times a month at bakso restaurant in Malang City. However, there are 52 respondents (24.77\%) who admit that 
on average in one year they sometimes never visit to Malang City. So, in month respondents don't necessarily enjoy bakso at bakso restaurants in Malang city (or if on average less than 1 time a year). This is because there may be respondents who claim to come from outside East Java (23 respondents, 10.95\%), even from outside Java Island (13 respondents, 6.19\%).

\section{Psychographic Segmentation of Bakso Culinary Tourists in Malang City}

Table 2. Attitudes Towards Food and Travelling: Three Segments

\begin{tabular}{|l|c|c|c|c|}
\hline \multicolumn{1}{|c|}{ Items } & Survivors & Enjoyers & Experiencers & Mean \\
\hline $\begin{array}{l}\text { How important are bakso as a food and eating } \\
\text { bakso as motives for travelling in Malang City? }\end{array}$ & $\begin{array}{c}\text { Mean Value } \\
2,00\end{array}$ & $\begin{array}{c}\text { Mean Value } \\
2,86\end{array}$ & $\begin{array}{c}\text { Mean Value } \\
3,76\end{array}$ & 3,69 \\
\hline $\begin{array}{l}\text { How important are bakso as a food and bakso } \\
\text { culinary experiences when choosing Malang } \\
\text { city for destination? }\end{array}$ & $\begin{array}{c}\text { Mean Value } \\
2,00\end{array}$ & $\begin{array}{c}\text { Mean Value } \\
2,88\end{array}$ & $\begin{array}{c}\text { Mean Value } \\
3,72\end{array}$ & 3,66 \\
\hline $\begin{array}{l}\text { How important are bakso as food and eating } \\
\text { bakso for travel satisfaction? }\end{array}$ & $\begin{array}{c}\text { Mean Value } \\
2,00\end{array}$ & $\begin{array}{c}\text { Mean Value } \\
2,86\end{array}$ & $\begin{array}{c}\text { Mean Value } \\
3,75\end{array}$ & 3,68 \\
\hline
\end{tabular}

Source: Survey Results (2021)

Tourist attitudes towards food and culinary travelling indicate certain types of Bakso culinary tourists. Psychographic segment can be measured from AIO (activities, interests and opinions) of consumers (Kotler, 2007). The survey results show that mean value about the importance of bakso as food and enjoying bakso (3.69), bakso as food and bakso culinary experiences when choosing Malang City for their destination (3.66), and bakso as food and enjoying bakso in seeking travel satisfaction (3.68) indicates that most of the respondents are Experiencers. Directly, Respondents have more interest in various factors, the existence of bakso as a one of local food and all behavioural attributes as an important aspect for influencing satisfaction of bakso culinary tourists in Malang city.

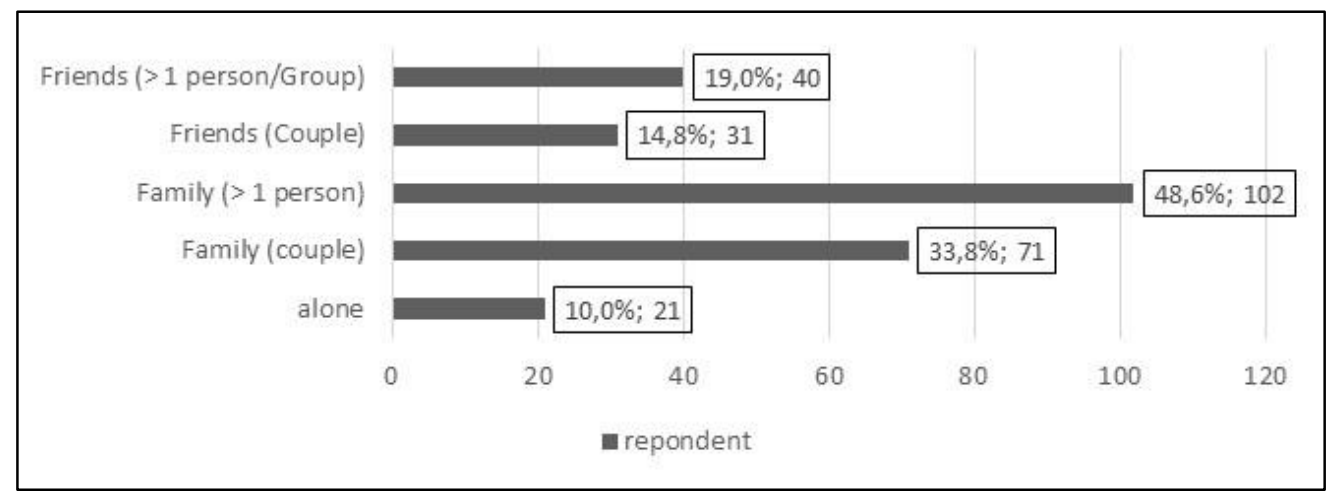

Figure 5. Partner to Visit Bakso Restaurant in Malang City Source: Survey Results (2021) 
Bakso as a food, enjoying bakso, bakso culinary experience and satisfaction as bakso culinary tourist are important factors to show respondent's attitudes regarding food and culinary tourism in Malang City. Meanwhile, partner for eating bakso at bakso Restaurants in Malang City are important to identify visiting tourist's model. Figure 5 shows that most of respondents enjoyed bakso at bakso restaurant in Malang City with more than one family (102 respondents, $48.6 \%$ ) or just with one family member (71 respondents, $33.8 \%)$. However, it is undeniable that any 21 respondents (10\%) who claim to enjoy bakso at bakso restaurant in Malang City by alone.

\section{Travellers' information sourcing behaviour related to culinary of Bakso Malang}

Table 3. Travellers' Information Sourcing Before Travelling

\begin{tabular}{|l|c|c|c|c|}
\hline \multicolumn{1}{|c|}{ Jenis Kelamin } & Survivors & Enjoyers & Experiencers & Mean \\
\hline $\begin{array}{l}\text { Do you collect information about bakso as } \\
\text { a local food tradition before travelling? }\end{array}$ & $\begin{array}{c}\text { Mean } \\
\text { Value 1,86 }\end{array}$ & $\begin{array}{c}\text { Mean } \\
\text { Value 2,70 }\end{array}$ & $\begin{array}{c}\text { Mean Value } \\
3,58\end{array}$ & 3,29 \\
\hline $\begin{array}{l}\text { Do you collect information about local } \\
\text { bakso restaurants before travelling? }\end{array}$ & $\begin{array}{c}\text { Mean } \\
\text { Value 1,86 }\end{array}$ & $\begin{array}{c}\text { Mean } \\
\text { Value 2,61 }\end{array}$ & $\begin{array}{c}\text { Mean Value } \\
3,57\end{array}$ & 3,15 \\
\hline
\end{tabular}

Source: Survey Results (2021)

Table 3 describes respondent's behavioural before going to bakso culinary tour in Malang city. They'll collect information related to bakso and bakso restaurant in Malang city by their self. This survey shows that most of respondents can be an Experiencer. They're agreed to seek information on local bakso in Malang (3.29) and local bakso restaurants in Malang (3.15) before traveling. There are various respondents who have main information source related to local bakso and local bakso restaurants in Malang city.

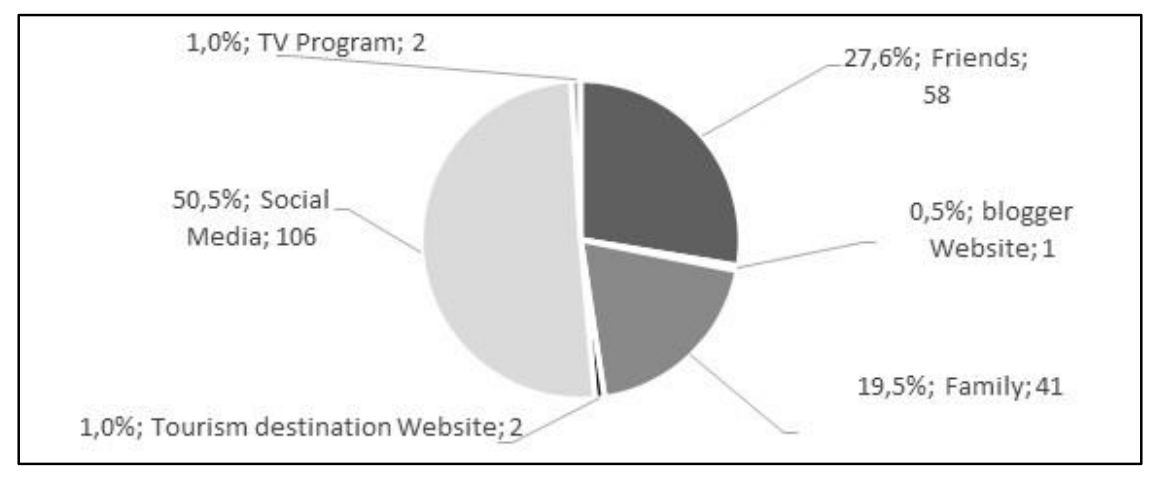

Figure 6. Use of Information Sources Before Travelling to Bakso Restaurant in Malang City Source: Survey Results (2021) 
Figure 6 describe that majority of respondents who enjoy bakso in Malang City get information from social media (106 respondents, 50.5\%). Information about bakso Malang dishes through social media is able to attract culinary tourists to visit various bakso restaurants in Malang City. World travel trends show that $70 \%$ of tourists are active users of social media, of which 1.5 million are active Facebook users. Meanwhile, $30 \%$ of world tourists are very active by using social media, both in determining travel decisions or activity in tourist destinations (ITB Berlin, 2015). Based on opinion from Hanggraito \& Sanjiwani (2020), social media is an important consideration in formulating marketing strategies to be cheaper and more efficient.

\section{Travellers' food-related experiences when eating Bakso Malang in Malang City}

Experiences about Bakso Malang are related to culinary activities, interest in food and personal opinions of culinary tourists. This survey shows the psychographic segmentation of culinary tourists who visit bakso restaurant to enjoy Bakso Malang in Malang city. Based on calculation of Mean value, there are various variables that can be used as assessment of respondent's experience related to bakso restaurant in Malang city. Various variables that are shown explicitly will show psychographics of respondent in culinary tourism.

Table 4. Characteristics of Local Food Experiences on Bakso Restaurant in Malang City

\begin{tabular}{|c|c|c|c|c|c|c|c|c|}
\hline \multirow{2}{*}{ Variable } & \multicolumn{3}{|c|}{ Mean Value } & \multirow[t]{2}{*}{$\mathrm{M}$} & \multicolumn{4}{|c|}{ Result (survey/percentage) } \\
\hline & Survivors & Enjoyers & Experiencers & & (1) & $(2)$ & (3) & $(4)$ \\
\hline \multirow{2}{*}{$\begin{array}{l}\text { Local food } \\
\text { culture }\end{array}$} & \multirow{2}{*}{1,93} & \multirow{2}{*}{2,70} & \multirow{2}{*}{3,46} & \multirow{2}{*}{3,15} & 3 & 39 & 91 & 77 \\
\hline & & & & & $1,4 \%$ & $18,6 \%$ & $43,3 \%$ & $36,7 \%$ \\
\hline \multirow{2}{*}{ Homemade food } & \multirow{2}{*}{2,00} & \multirow{2}{*}{2,82} & \multirow{2}{*}{3,53} & \multirow{2}{*}{3,38} & 0 & 20 & 90 & 100 \\
\hline & & & & & $0,0 \%$ & $9,5 \%$ & $42,9 \%$ & $47,6 \%$ \\
\hline \multirow{2}{*}{$\begin{array}{l}\text { The newness of } \\
\text { food }\end{array}$} & \multirow{2}{*}{1,90} & \multirow{2}{*}{2,67} & \multirow{2}{*}{3,40} & \multirow{2}{*}{3,03} & 5 & 47 & 95 & 63 \\
\hline & & & & & $2,4 \%$ & $22,4 \%$ & $45,2 \%$ & $30,0 \%$ \\
\hline \multirow{2}{*}{$\begin{array}{l}\text { Food } \\
\text { authenticity }\end{array}$} & \multirow{2}{*}{1,95} & \multirow{2}{*}{2,79} & \multirow{2}{*}{3,62} & \multirow{2}{*}{3,46} & 1 & 19 & 72 & 118 \\
\hline & & & & & $0,5 \%$ & $9,0 \%$ & $34,3 \%$ & $56,2 \%$ \\
\hline \multirow{2}{*}{ Local food } & \multirow{2}{*}{1,83} & \multirow{2}{*}{2,79} & \multirow{2}{*}{3,47} & \multirow{2}{*}{3,24} & 5 & 25 & 95 & 85 \\
\hline & & & & & $2,4 \%$ & $11,9 \%$ & $45,2 \%$ & $40,5 \%$ \\
\hline \multirow{2}{*}{ Original food } & \multirow{2}{*}{1,88} & \multirow{2}{*}{2,79} & \multirow{2}{*}{3,54} & \multirow{2}{*}{3,34} & 3 & 23 & 84 & 100 \\
\hline & & & & & $1,4 \%$ & $11,0 \%$ & $40,0 \%$ & $47,6 \%$ \\
\hline Hoalthy fond & 188 & 265 & 336 & 204 & 7 & 52 & 97 & 54 \\
\hline Healthy tood & 1,88 & 2,65 & 3,36 & 2,94 & $3,3 \%$ & $24,8 \%$ & $46,2 \%$ & $25,7 \%$ \\
\hline The uniqueness & 200 & 282 & 352 & 320 & 0 & 19 & 91 & 100 \\
\hline of food & 2,00 & 2,83 & 3,52 & 3,39 & $0,0 \%$ & $9,0 \%$ & $43,3 \%$ & $47,6 \%$ \\
\hline Participation in & & & & & 13 & 31 & 89 & 77 \\
\hline food preparation & 1,70 & 2,74 & 3,46 & 3,10 & $6,2 \%$ & $14,8 \%$ & $42,4 \%$ & $36,7 \%$ \\
\hline W/llknoun food & 20 & 207 & 215 & 212 & 0 & 4 & 113 & 93 \\
\hline Well-known tood & 2,00 & 2,97 & 3,45 & 3,42 & $0,0 \%$ & $1,9 \%$ & $53,8 \%$ & $44,3 \%$ \\
\hline
\end{tabular}




\begin{tabular}{|c|c|c|c|c|c|c|c|c|}
\hline \multirow{2}{*}{ Variable } & \multicolumn{3}{|c|}{ Mean Value } & \multirow[t]{2}{*}{$\mathrm{M}$} & \multicolumn{4}{|c|}{ Result (survey/percentage) } \\
\hline & Survivors & Enjoyers & Experiencers & & $(1)$ & $(2)$ & (3) & $(4)$ \\
\hline \multirow{2}{*}{$\begin{array}{l}\text { Different style of } \\
\text { eating }\end{array}$} & \multirow{2}{*}{1,92} & \multirow[b]{2}{*}{2,65} & \multirow{2}{*}{3,41} & \multirow{2}{*}{3,03} & 4 & 49 & 93 & 64 \\
\hline & & & & & $1,9 \%$ & $23,3 \%$ & $44,3 \%$ & $30,5 \%$ \\
\hline \multirow{2}{*}{$\begin{array}{l}\text { Dining } \\
\text { companionship }\end{array}$} & \multirow{2}{*}{1,58} & \multirow{2}{*}{2,92} & \multirow{2}{*}{3,60} & \multirow{2}{*}{3,48} & 5 & 7 & 80 & 118 \\
\hline & & & & & $2,4 \%$ & $3,3 \%$ & $38,1 \%$ & $56,2 \%$ \\
\hline \multirow{2}{*}{ Food aesthetics } & \multirow{2}{*}{1,87} & \multirow{2}{*}{2,64} & \multirow{2}{*}{3,33} & \multirow{2}{*}{2,90} & 8 & 55 & 98 & 49 \\
\hline & & & & & $3,8 \%$ & $26,2 \%$ & $46,7 \%$ & $23,3 \%$ \\
\hline \multirow{2}{*}{$\begin{array}{l}\text { Dining in } \\
\text { restaurants }\end{array}$} & \multirow{2}{*}{1,67} & \multirow{2}{*}{2,98} & \multirow{2}{*}{3,54} & \multirow{2}{*}{3,51} & 1 & 2 & 95 & 112 \\
\hline & & & & & $0,5 \%$ & $1,0 \%$ & $45,2 \%$ & $53,3 \%$ \\
\hline \multirow{2}{*}{$\begin{array}{l}\text { Restaurant } \\
\text { environment }\end{array}$} & \multirow{2}{*}{1,83} & \multirow{2}{*}{2,84} & \multirow{2}{*}{3,44} & \multirow{2}{*}{3,26} & 4 & 20 & 104 & 82 \\
\hline & & & & & $1,9 \%$ & $9,5 \%$ & $49,5 \%$ & $39,0 \%$ \\
\hline \multirow{2}{*}{$\begin{array}{l}\text { The restaurant } \\
\text { atmosphere }\end{array}$} & \multirow{2}{*}{1,88} & \multirow{2}{*}{2,84} & \multirow{2}{*}{3,42} & \multirow{2}{*}{3,25} & 3 & 21 & 107 & 79 \\
\hline & & & & & $1,4 \%$ & $10,0 \%$ & $51,0 \%$ & $37,6 \%$ \\
\hline \multirow{2}{*}{$\begin{array}{l}\text { The absence of } \\
\text { stress }\end{array}$} & \multirow{2}{*}{1,91} & \multirow{2}{*}{2,77} & 3.46 & 322 & 3 & 29 & 96 & 82 \\
\hline & & & 3,46 & 3,22 & $1,4 \%$ & $10,0 \%$ & $51,0 \%$ & $37,6 \%$ \\
\hline
\end{tabular}

Source: Survey Results (2021)

Table 4 show the characteristics of Bakso Malang based on culinary experiences from respondents when traveling to bakso restaurant in Malang City. All variables indicate that the type of bakso culinary tourist in Malang City for psychographic segmentation is Experiencer. This is because most respondents agree with all experiences related to food at various bakso restaurants in Malang City. Table 4 explain that culinary experience obtained when respondents take a culinary tour at bakso restaurants such as; Uniqueness of food $(M=3.39$; 191 respondents), well-known food ( $M=3.42 ; 206$ respondents), Food authenticity ( $M=3.46$; 190 respondents), Dining Companionship ( $M=3.48$; 198 respondents), and Dining in restaurant $(M=3.51 ; 207$ respondents). Dining in restaurants is the most variable widely approved as a characteristic of culinary tourism.

According to respondents, there are several variables that have less impact on the culinary experience. Especially, when they enjoy bakso in bakso restaurant in Malang. the variables in question are; food aesthetics ( $M=2.90 ; 63$ respondents), Healthy food ( $M=2.90 ; 59$ respondents), Food novelty ( $M=3.03 ; 52$ respondents), Different eating styles $(M=3.03 ; 53$ respondents), and Participation in food preparation ( $M=3.1 ; 44$ respondents). Food aesthetics are less perceived by respondents as a food-related experience when enjoying bakso in Malang City. There are several bakso restaurants that are most frequently visited in Malang City, namely the President's Meatball Restaurant (64.8\%; 133 respondents), Cak Man City Meatballs (63.3\%; 133 respondents), and Bakso Bakar Pak Man. (58.6\%; 133 respondents). In general, food aesthetics in bakso restaurants does not highlight as a variable that very 
affected the culinary experience of meatball culinary tourists in Malang City. According to blogger website like tripadvisor.co.id, here are some opinions from some bakso tourists.

"Baksonya legend dan super-duper serunya karena posisi berada di samping rel kereta api, jadi pas lagi asyik-asyiknya menikmati baksonya...tiba-tiba lewat kereta api...jadi kalo ke Malang belum mampir ke sini berarti belum lengkap rasanya" $(\mathrm{O}$, Malang, tripadvisor.co.id, 2019).

"You can buy a bowl of meatballs (and also the side dish like noodle, tofu, and many more, you can add up the dishes by yourself) with only 20k rupiahs, and delicious 'tahu-lontong' with only 10k rupiahs. And I loved it sooooo much! You can sit on the chair, or feel the 'lesehan' being. You can eat during the street singers sing the lullaby song with their guitars. Yeah, you can catch the nostalgic atmosphere of Malang there!" ( $T$, Surabaya, tripadvisor.co.id, 2017).

"In here you must self-service. If you want order bakso bakar you will have to ask how many do you want, then they will serve it later on. Great taste of bakso bakar. After you finished don't forget to pay. Just remember how many that u ate already." (D, Jakarta, tripadvisor.co.id, 2017).

Documentation results from comments on the tripadvisor.co.id show the uniqueness of food (3.39), Dining in restaurants (3.51), The restaurant atmosphere (3.25), and Food authenticity (3.46) are some variables that indirectly provide a bakso culinary experience. According to Kotler (2010) in Laksono (2019), aesthetics is where a product can be seen and felt directly the beauty of the product. However, this is not the main variable in the food-related experience for bakso culinary tourists in Malang City.

\section{Motivation culinary Tourist of Bakso Malang in Malang City}

Table 5 shows that the main motivational factors for visiting various bakso restaurants in Malang City are hedonism and leisure (3.37). Respondents who travel to bakso culinary have the motivation of hedonism and leisure in Malang City, with indicators: Spend time with relatives, friends, colleagues (3.25), Being a leisure (3.44), and good quality/price relationship (3.40). The motivation related to leisure time and being close to the house is the reason for someone making a bakso culinary tour in Malang city. One of the reasons is the family as a partner for culinary tourism. Referred to, families with more than one person (102 respondents, $48.6 \%$ ) or alone with one family member (71 respondents, $33.8 \%$ ).

Table 5. Analysis of Motivation to Eating at Bakso Restaurant in Malang City 


\begin{tabular}{|c|c|c|c|c|c|}
\hline \multirow{2}{*}{ Motivation } & \multicolumn{4}{|c|}{ Result (survey/percentage) } & \multirow{2}{*}{ M } \\
\hline & (1) & (2) & (3) & (4) & \\
\hline \multicolumn{6}{|c|}{ Food experience and novelty } \\
\hline \multirow{2}{*}{ New eating / drinking experiences } & 9 & 36 & 86 & 79 & \multirow{2}{*}{3,12} \\
\hline & $4,29 \%$ & $17,14 \%$ & $40,95 \%$ & $37,62 \%$ & \\
\hline \multirow{2}{*}{ Fame and reputation of the market } & 1 & 11 & 76 & 122 & \multirow{2}{*}{3,52} \\
\hline & $0,48 \%$ & $5,24 \%$ & $36,19 \%$ & $58,10 \%$ & \\
\hline \multirow{2}{*}{ Relaxation, disconnection from daily life } & 9 & 32 & 84 & 85 & \multirow{2}{*}{3,17} \\
\hline & $4,29 \%$ & $15,24 \%$ & $40,00 \%$ & $40,48 \%$ & \\
\hline \multirow{2}{*}{ Desire to do new things } & 6 & 28 & 85 & 91 & \multirow{2}{*}{3,24} \\
\hline & $2,86 \%$ & $13,33 \%$ & $40,48 \%$ & $43,33 \%$ & \\
\hline \multirow{2}{*}{$\begin{array}{l}\text { Eat/drink my favourite food/drink } \\
\text { (reputation) }\end{array}$} & 0 & 12 & 89 & 109 & \multirow{2}{*}{3,46} \\
\hline & $0,00 \%$ & $5,71 \%$ & $42,38 \%$ & $51,90 \%$ & \\
\hline \multirow{2}{*}{ Average } & 5,00 & 23,80 & 84,00 & 97,20 & \multirow{2}{*}{3,30} \\
\hline & $2,38 \%$ & $11,33 \%$ & $40,00 \%$ & $46,29 \%$ & \\
\hline \multicolumn{6}{|c|}{ Hedonism and leisure } \\
\hline \multirow{2}{*}{$\begin{array}{l}\text { Spend time with relatives, friends, } \\
\text { colleagues }\end{array}$} & 7 & 29 & 78 & 96 & \multirow{2}{*}{3,25} \\
\hline & $3,33 \%$ & $13,81 \%$ & $37,14 \%$ & $45,71 \%$ & \\
\hline \multirow{2}{*}{ Being a leisure } & 1 & 17 & 80 & 112 & \multirow{2}{*}{3,44} \\
\hline & $0,48 \%$ & $8,10 \%$ & $38,10 \%$ & $53,33 \%$ & \\
\hline \multirow{2}{*}{ Good quality/price relationship } & 4 & 13 & 88 & 105 & \multirow{2}{*}{3,40} \\
\hline & $1,90 \%$ & $6,19 \%$ & $41,90 \%$ & $50,00 \%$ & \\
\hline \multirow{2}{*}{ Average } & 4,00 & 19,67 & 82,00 & 104,33 & \multirow{2}{*}{3,37} \\
\hline & $1,90 \%$ & $9,37 \%$ & $39,05 \%$ & $49,68 \%$ & \\
\hline \multicolumn{6}{|c|}{ Relationship of the experience with work } \\
\hline \multirow{2}{*}{ Do business or work } & 68 & 66 & 38 & 38 & \multirow{2}{*}{2,22} \\
\hline & $32,38 \%$ & $31,43 \%$ & $18,10 \%$ & $18,10 \%$ & \\
\hline \multirow{2}{*}{ Networking } & 64 & 60 & 50 & 36 & \multirow{2}{*}{2,28} \\
\hline & $30,48 \%$ & $28,57 \%$ & $23,81 \%$ & $17,14 \%$ & \\
\hline \multirow{2}{*}{ Average } & 66 & 63 & 44 & 37 & 225 \\
\hline & $31,43 \%$ & $30,00 \%$ & $20,95 \%$ & $17,62 \%$ & 2,25 \\
\hline
\end{tabular}

Source: Survey Results (2021)

\section{Understanding of Market Segmentation and Motivation Bakso Culinary Tourist in Malang City}

This study shows that an important capital in the sustainable development strategy of a culinary tourism in Malang City is market strengthening. culinary tourists who have visited various bakso restaurants in Malang city provide an understanding of the tourists' model. The Experiencers for bakso culinary tourism focus on Food Uniqueness, Well-Known Food, Food Authenticity, Dining Companionship, and Dining in restaurant at various Bakso Restaurants in Malang City. Enjoying Bakso directly at various restaurants in Malang City is the main reason for increasing food-related tourism experiences. The uniqueness of Bakso Malang is different from other bakso, 
"Bakso Malang yang memiliki banyak sekali varian, seperti bakso urat, bakso keju, bakso cabai rawit, bakso sosis, bakso telur puyuh, dan bakso sumsum" (Leonardo, brillio.net, 2018).

Bakso can be understood as a local food that is full of cultural capital, and each restaurant has a different atmosphere and way of enjoying. The sensation of enjoying local food in the destination with cultural capital can provide private motivation for tourists (Hanggraito \& Budiani, 2021). There are several explanations for the dining experience related to the place of several bakso restaurants in Malang City.

\footnotetext{
"Tak hanya baksonya yang menarik, sensasi makan bakso President juga unik. Pengunjung makan persis di samping rel kereta yang masih aktif, jadi ada sensasi serunya" (Setya, food.detik.com, 2018).

"Cara penyajian di Bakso Gun itu tentu sangat berbeda dengan di tempat-tempat lain, terutama karena cara ini dapat membuat hidangan dapat terjaga kehangatannya dan sangat cocok untuk dimakan bersama-sama dan berbagi panci bersama" (Permana, merdeka.com, 2016).
}

Comments about the sensation of eating directly at places such as Bakso President and Bakso Gun show the importance of a sense of place at Bakso Restaurant in Malang City. In addition, food and the feeling of enjoying food in multiple places can be important assets in culinary tourism management. Food experiences can also be seen as playing a role in the vibrancy and attractiveness of places in general, not just for tourists, but also for people living in or investing in those places (Richards, 2012). Indirectly, dining companionship and dining in restaurant provide various experiences related to the sensation of eating bakso on site. This fact has caused many restaurants to have variants of bakso and provide different feelings when visitors enjoy bakso.

In addition, the main motivating factor of bakso restaurants visiting in Malang City is related to hedonism and leisure. This understanding includes three aspects: enjoy the time with relatives and friends, leisure activities, and a good quality-price relationship. Leisure activity can be the main motivation variable for visit and enjoy bakso at various restaurants in Malang City. Those who come from the city of Malang (53.8\%) can make a bakso restaurant to leisure in culinary activities. In fact, there are statements related to hedonism and leisure factors that support the motivation of bakso culinary tourism.: 
"Percuma pulang kampung ke Malang kalau tidak berwisata kuliner. Apalagi kalau tidak mencoba bakso Malang, itu namanya rugi besar. Sempatkanlah walau hanya sekali ke beberapa gerai bakso khas Malang" (Ramadhany, travel.detik.com, 2015)

This shows that, for those from outside Java Island (6.19\%) enjoying bakso. When visiting Malang City, it can be used as a nostalgic feeling in their hometown in Malang city.

\section{CONCLUSIONS}

The sustainability of Bakso Malang as one of Indonesian traditional meatballs can define local product management from the perspective of culinary tourism concepts. The study on the segmentation market of bakso culinary in Malang city shows that the main types are Experiencers. Psychographic segmentation based on the culinary experience of bakso in Malang City is tied to five main variables, Uniqueness of food, well-known food, Food authenticity, Dining Companionship, and Dining in the restaurant. A culinary tourism development not only focuses on the local food aspect but also on cultural capital and restaurant atmosphere. Bakso culinary tourist segment in Malang City is a justification for factors that can motivate tourists to visit a culinary destination. Social media can be the main source of information for bakso culinary tourists in Malang city. This explains the importance of bakso restaurant management strategy through social media as product marketing in the technological age. This study shows that the main motivation of bakso culinary tourists in Malang City is related to hedonism and leisure factors. The factor of leisure activities is the main driving force of Bakso culinary tourism in Malang City. Restaurant managers can improve many aspects of restaurant dining, which is an important point to increase the comfort of incoming cooking tourists. In the end, market segmentation and the bakso culinary tourist's motivation in Malang City shows that "bakso" have become a part of the consistent development of sustainable culinary tourism in Indonesia.

This study is a continued attempt to explore the link between food attitudes and behavior related to local food in psychographic segmentation and motivational factors within culinary tourism. the study has some limitations, which provide materials for the further research. First, 
this study has a main focus in type on psychographic segmentation regarding to food-related experiences. The result could provide other ways for further research. Second, this study has a limited method. Future research could use larger sample size and various focus of research. This is because in-depth research related to culinary tourism in Indonesia is very limited in terms of quality and quantity. Third, the motivational factors could be replaced by other theories for future research. It could also make comparisons with variables in this research with other culinary foods.

\section{REFERENCES}

Assauri, S. (2015). Manajemen Pemasaran, Edisi 15. Jakarta: Rajawali Perseda.

Ayustina, R. D. (2019). The Current Practices of Extensive Reading in Literature Class (Descriptive Qualitative Study at the Third Semester Students of English Education Study Program of IAIN Bengkulu in Academic Year 2018/2019). Thesis. English Letters Study program, Islamic Education `and Tadris Faculty.

Björk, P., \& Kauppinen-Räisänen, H. (2016). Local food: A source for destination attraction. International Journal of Contemporary Hospitality Management, 28(1), 177-194. https://doi.org/10.1108/lJCHM-05-2014-0214.

Castillo-Canalejo, A. M., Sánchez-Cañizares, S. M., Santos-Roldán, L., \& Muñoz-Fernández, G. A. (2020). Food Markets: A Motivation-Based Segmentation of Tourists. International Journal of Environmental Research and Public Health, 17(7), 2312.

Cho, M., Bonn, M. A., \& Brymer, R. A. (2014). A Constraint-Based Approach to Wine Tourism Market Segmentation. Journal of Hospitality \& Tourism Research, 41(4), 415-444. doi:10.1177/1096348014538049.

Freeman, M., deMarrais, K., Preissle, J., Roulston, k., \& Pierre, E.A.S. (2007). Standards of Evidence in Qualitative Research: An Incitement to Discourse. Educational Researcher, Vol. 36, No. 1, pp. 25-32 DOI: 10.3102/0013189X06298009.

Hanggraito, A.A., \& Budiani. (2021). Eksplorasi segmentasi pasar dan motivasi wisatawan kuliner di gudeg pawon Yogyakarta. JUMPA Volume 7, Nomor 2, Januari 2021.

Hanggraito, A.A., \& Sanjiwani, N.M.G. (2020). Tren Segmentasi Pasar dan Perilaku Wisatawan Taman Bunga Amaryllis di Era 4.0. Journal of Tourism and Creativity. Vol.4 No.1 Januari 2020. e-ISSN: 2716-5159.

Hartono, B., Ningsih, U. W., \& Septiarini, N, F. (2011). Perilaku konsumen dalam pembelian bakso di malang. Buletin Peternakan Vol. 35(2): 137-142, Juni 2011. ISSN 0126-4400.

Kemenparekraf. (2019). Pedoman Pengembangan Wisata Kuliner. Asisten Deputi Pengembangan Wisata Budaya Deputi Bidang Pengembangan Industri dan Kelembagaan Kementerian Pariwisata. Jakarta.

Kim, Y., Eves, A. and Scarles, C. (2009), "Building a model of local food consumption on trips and holidays: a grounded theory approach", International Journal of Hospitality Management, Vol. 28 No. 3, pp. 423-431.Kotler, P. (2007). Marketing Management. Beijing: Tsinghua University Press.

Laksono, P. (2019). Pengaruh brand image dan penentuan lokasi terhadap Persepsi dan loyalitas konsumen bakso mas "bakar" di Kota serang (studi kasus). PUBLIK Jurnal IImiah Ekonomi Sekolah Tinggi Ilmu Ekonomi Banten. Vol. 15 No. 1 Februari 2019. ISSN: 16935236. 
Leewellyn, V. S., \& Abdillah, F. (2020). Inventarisasi Konsep Ekosistem Pariwisata Dalam Pengembangan Destinasi Wisata Berkelanjutan: Kasus Waduk Walahar, Kabupaten Karawang. Destinesia: Jurnal Hospitaliti dan Pariwisata Vol 1, No. 2, Maret 2020, pp. 5767. E-ISSN 2686-2042.

Long, L. (2004). Culinary tourism. Lexington, KY: The University Press of Kentucky.

Long, L. (2013). Culinary Tourism. Encyclopedia of Food and Agricultural Ethics. DOI 10.1007/978-94-007-6167-4_416-1.

Mak, A.H.N., Lumbers, M., Eves, A., \& Chang, R.C.Y. (2012). Factors influencing tourist food consumption. International Journal of Hospitality Management, 31, 928-936. https://doi.org/10.1016/j.ijhm.2011.10.012.

Purnomo, H. and Rahardiyan, D. (2008). Indonesian Traditional Meatball. International Food Research Journal 15(2): 101-108(2008).

Rahardiyan, D. (2004). Bakso (traditional Indonesian meatball) properties with postmortem condition and frozen storage. Thesis. Louisiana State University and Agricultural and Mechanical College.

Richards, G. (2012) Food and the tourism experience: major findings and policy orientations. In Dodd, D. (ed.) Food and the Tourism Experience. OECD, Paris, pp. 13-46.

Soecahyadi. (2012). Analaisa Statistik dengan Aplikasi SPSS. - Edisi Pertama - Jakarta; Usahid Jakarta. ISBN: 978-602-74689-2-4.

Statistics Malang Municipality. (2021). Malang Municipality in Figures 2021. BPS Kota Malang. ISSN: 0215-5975.

Sudaryono. (2019). Metodologi Penelitian: Kuantitatif, Kualitatif, dan Mix Method. Ed. 2. Depok: Rajagrafindo Persada.

Suryana. (2010). Metodologi Penelitian: Metodologi Penelitian Model Prakatis Penelitian Kuantitatif dan Kualitatif. Bandung: Universitas Pendidikan Indonesia.

Tarwotjo, I., Hartini, S., Soekirman, S., dan Soekarno. (1971). Komposisi Tiga Jenis Bakso. Jakarta.: Akademi Gizi.

Umar, H. (2013). Metode Penelitian untuk Skripsi dan Tesis. Jakarta: Rajawali.

UNWTO. (2017). Global Report on Food Tourism. Madrid: World Tourism Organization.

Wijayanti, A. (2020). Wisata Kuliner Sebagai Strategi Penguatan Pariwisata Di Kota Yogyakarta, Indonesia. Khasanah IImu: Jurnal Pariwisata Dan Budaya. Volume 11 Nomor 1, Maret 2020 ISSN: 2087-0086 (print), 2655-5433 (online). DOI: 10.31294/khi. v11i1.7998

\section{Internet}

ITB Berlin. (2015). ITB World Travel and Trends Report 2015 - 2016. Retrieved from https://www.itb-berlin.de/media

Leonardo, C. (2018). Sama-sama nikmat, inilah perbedaan Bakso Malang dan Bakso Solo. Retrieved from https://www.brilio.net/creator/sama-sama-nikmat-inilah-perbedaanbakso-malang-dan-bakso-solo-f6d172.html

Permana, R. W. (2016). Menikmati penyajian di panci dari Bakso Gun. Retrieved from https://www.merdeka.com/malang/kuliner/menikmati-penyajian-di-panci-dari-bakso-gun1607024.html

Setya, D. (2018). Mantap! 5 Bakso di Malang Ini Terkenal Enak dan Legendaris. Retrieved from https://food.detik.com/info-kuliner/d-4303439/mantap-5-bakso-di-malang-initerkenal-enak-dan-legendaris

Ramadhany, F. (2015). 7 Tempat Wisata di Malang yang Bikin Kangen Pulang Kampung. Retrieved from https://travel.detik.com/domestic-destination/d-2958858/7-tempat-wisatadi-malang-yang-bikin-kangen-pulang-kampung/5?v99110313811= 